\title{
Training on writing COVID-19 slogans for teens and basic food assistance for angkot drivers affected by the pandemic
}

\author{
Nur Amalia a,1, N. Nawawi ${ }^{\mathrm{a}, 2}$, Nur Aini Puspitasari a,3 \\ a Universitas Muhammadiyah Prof. Dr. HAMKA, JI. Limau II, RT.3/RW.3, Kramat Pela, Kec. Kby. Baru, Kota Jakarta Selatan, Daerah Khusus Ibukota \\ Jakarta 12130, Indonesia \\ 1nur21amalia@gmail.com, 2nawawi_msi@yahool.com,3nuraini_puspitasari@gmail.com \\ *Corresponding author
}

\begin{tabular}{|c|c|}
\hline ARTICLE INFO & ABSTRACT \\
\hline $\begin{array}{l}\text { Article history } \\
\text { Received: 2020-08-14 } \\
\text { Revised: 2021-04-04 } \\
\text { Accepted: 2021-04-06 } \\
\text { Published: 2021-04-30 } \\
\\
\text { Keywords } \\
\text { Angkot drivers } \\
\text { COVID-19 } \\
\text { Slogan } \\
\text { Teens } \\
\text { Training on writing }\end{array}$ & $\begin{array}{l}\text { Activities to implement one of the Tridharma Perguruan Tinggi to continue to share knowledge and } \\
\text { share basic needs with communities affected by COVID-19 need to be done. This activity aims to } \\
\text { provide training in writing COVID-19 slogans for adolescents and providing groceries for Ciputat- } \\
\text { Parung Angkot Drivers who are affected by COVID-19. The activity was held in May 2020. The activity } \\
\text { was carried out well and was welcomed by the community. This is evidenced by the enthusiasm of } \\
\text { teenagers in writing COVID-19 slogans and being able to foster a spirit of creativity and productivity } \\
\text { so that they can raise awareness of teenagers. }\end{array}$ \\
\hline $\begin{array}{l}\text { Kata kunci } \\
\text { Supir angkot } \\
\text { COVID-19 } \\
\text { Slogan } \\
\text { Remaja } \\
\text { Pelatihan menulis } \\
\text { D) Check for updates }\end{array}$ & $\begin{array}{l}\text { Pelatihan penulisan slogan COVID-19 untuk remaja dan bantuan sembako bagi pengemudi angkot } \\
\text { yang terkena pandemi. Kegiatan menerapkan salah satu Tridharma Perguruan Tinggi untuk terus } \\
\text { berbagi ilmu dan berbagi kebutuhan dasar dengan komunitas yang terdampak COVID-19 perlu } \\
\text { dilakukan. Kegiatan ini bertujuan untuk memberikan pelatihan menulis slogan COVID-19 bagi remaja } \\
\text { dan pemberian sembako bagi para Sopir Angkot Ciputat-Parung yang terdampak COVID-19. Kegiatan } \\
\text { dilaksanakan pada bulan Mei 2020. Kegiatan terlaksana dengan baik dan disambut baik oleh } \\
\text { masyarakat. Hal tersebut dibuktikan dengan antusiasme para remaja dalam menulis slogan COVID- } \\
19 \text { serta mampu menumbuhkan semangat kreativitas dan produktivitas sehingga mampu } \\
\text { menumbuhkan kesadaran para remaja. } \\
\text { This is an open access article under the CC-BY-SA license }\end{array}$ \\
\hline
\end{tabular}

How to cite: Amalia, N. Nawawi, N., \& Puspitasari, N.A. (2021). Training on writing COVID-19 slogans for teens and basic food assistance for angkot drivers affected by the pandemic. Journal of Community Service and Empowerment, 2 (1), 35-40. https://doi.org/10.22219/ jcse.v2i1.13265

\section{PENDAHULUAN}

Awal tahun 2020 dunia dikejutkan oleh berita yang menghebohkan dunia, munculnya corona jenis virus yang berasal dari Wuhan-China pada bulan Desember 2019. Virus ini sekarang dikenal dengan nama COVID-19 (Corona Virus Disease 2019). Virus ini menjadi momok bagi masyarakat dikarenakan penularannya yang sangat cepat, dan sudah menyebar ke semua negara termasuk Indonesia dalam waktu yang relatif singkat/beberapa bulan (Cirrincione et al., 2020; Dube, 2020; Yang et al., 2020; Yuliana, 2020). Virus yang menyerang pernafasan ini masih satu kelompok dengan virus penyebab SARS (Severe Acute Respiratory Sydrome dan MERS Cov. Sebagian orang yang terinveksi virus corona mengalami gejala flu, namun ada yang mengalami gejala berat akibat pneumonia. Efek dari virus COVID-19 ini dapat menyebabkan gangguan saluran pernafasan dan infeksi paru-paru yang berat (Sharma et al., 2020; Wu et al., 2020; Yi et al., 2020).

Begitu seriusnya penanganan upaya pencegahan ini dilakukan, pemerintah telah melakukan pelarangan penyelenggaraan yang mengudang banyak orang untuk berkumpul dengan cara meliburkan sekolah, meliburkan kantor- 
kantor, dan membatasi jumlah penumpang angkutan umum seperti trans Jakarta, bis, kereta api, pesawat udara, dan angkot.

Jumlah penderita COVID-19 yang terus bertambah akibat sulitnya mengedukasi masyarakat akan pentingnya "di rumah aja", kalaupun terpaksa harus ke luar rumah, maka harus mengikuti aturan yang telah dibuat pemerintah. Dalam hal ini pemerintah sangat berhati-hati dalam menerapkan kebijaksanaan dan sanksi kepada masyarakat yang tidak mau patuh dengan aturan yang telah ditetapkan. Hal ini mengakibatkan pemerintah menerapkan PSBB (Fatimah et al., 2020; Suryani, 2020; Udin, 2020).

Penerapan PSBB berdampak kepada banyak hal, seperti mall yang sepi dari pengunjung, rumah-makan banyak yang tutup karena tidak ada pembeli-karyawan banyak di rumahkan. Akibatnya berdampak langsung pada angkutan umum yang sepi penumpang, karena masyarakat malas ke luar rumah. Salah satu yang terdampak COVID-19 adalah sopir angkot.

Ide untuk memberikan santunan kepada sopir angkot, dilatar belakangi dari observasi pada setiap angkot yang lewat, isi penumpangnya hanya 1-2, selebihnya malah kosong. Dari hasil wawancara dengan 15 sopir angkot diperoleh informasi, bahwa hasil yang mereka peroleh sejak mewabahnyanya COVID-19 jauh dari biasanya, dan tak jarang mereka pulang ke rumah tanpa membawa hasil, untuk setoran saja terkadang tidak terpenuhi.

Pengabdian masyarakat adalah salah satu kegiatan dari Tridarma Perguruan Tinggi yang harus dilakukan oleh Dosen. Kegiatan ini bertujuan untuk memberikan pelatihan menulis slogan COVID-19 bagi remaja dan pemberian sembako bagi para Sopir Angkot Ciputat-Parung yang terdampak COVID-19, sebagai wujud dari Tridarma Perguruan Tinggi. Sebagai salah satu wujud dari kepedulian tim Uhamka pada masyarakat dalam penanggulangan COVID-19, tim berusaha untuk menanamkan pemahaman kepada para remaja desa Kasemen dengan perlunya mematuhi protokol pencegahan pandemic COVID-19 dengan stay at home, work at home, dan social distancing. Kondisi lockdown yang diterapkan pemerintah membuat kami, tim Pengmas Prodi Pendidikan Bahasa dan Sastra Indonesia FKIP UHAMKA tidak dapat melakukan kegiatan ini bersama-sama secara fisik, tetapi dengan bantuan teknologi komunikasi Zoom meeting kegiatan ini dapat kami lakukan.

Topik menulis slogan COVID-19 bagi remaja Desa Kasemen diharapkan dapat memotivasi orang lain dan menyadarkan masyarakat akan pentingnya upaya paham diri dan keluarga dari virus COVID-19 dengan mematuhi aturan yang telah diterapkan pemerintah demi melindungi rakyat Indonesia dari kejadian yang tidak diinginkan. Slogan ini diharapkan menjadi perpanjangan tangan dari tim UHAMKA membantu pemerintah dalam menyadarkan/mengingatkan masyarakat tentang perlunya mengikuti protokoler pergi dan pulang ke rumah sebagai upaya pencegahan penularan COVID-19 dengan Stay at home, work from home dan social ditancing.

\section{METODE}

Solusi yang ditawarkan bagi permasalahan mitra di desa Kasemen, Serang, Banten, adalah seperti pada Tabel 1.

Tabel 1. Permasalan, solusi, dan luaran

\begin{tabular}{ll}
\hline No. & Permasalahan \\
\hline 1 & Minat remaja yang rendah \\
& dalam menulis slogan karena \\
& minimnya penguasaan kosa kata
\end{tabular}

2 Kurangnya penguasaan diksi yang mengakibat-kan kurangnya keper-cayaan diri

3 Kurang tersedianya bahan bacaan/buku-buku yang mereka sukai terutama yang berkaitan dengan teori dan buku kumpulan slogan

4. Perlunya kerja sama yang terjalin antara remaja dan orang tua

5. Remaja Desa kasemen, SerangBanten kurang paham cara menulis slogan

6. Kurang paham cara menulis slogan COVID-19

7. Pembelajaran menulis slogan belum maksimal di sekolah,

Solusi yang ditawarkan

Menggali kosa kata remaja yang berhubungan

dengan covid- 19

Tim meminta menuliskan daftar kosa kata yang sudah mereka miliki dan mendaftar kosa kata sulit yang kurang dipahami.

Menggali diksi remaja. Tim akan menggali diksi, misalnya: menuliskan daftar diksi yang sudah mereka miliki.

Menambah bahan bacaan yang mereka sukai, menuliskan hal-hal yang mereka sukai dan mereka temukan di sekitar mereka.

Dibentuk kelompok diskusi dan remaja diminta untuk menyampaikan ide dan gagasannya.

Remaja Desa Kasemen diajarkan bagaimana cara memahami slogan dan membimbing remaja cara menulis slogan

Remaja desa kasemen diajarkan cara menulis slogan.

Siswa harus aktif-kreatif mencari contoh beberapa slogan kemudian lalu menulis slogan

\section{Luaran}

Terbentuknya kelompok

belajar keterampilan menggali

kosa kata

Terbentuknya kelompok belajar remaja terampil menggunakan diksi

Tercapainya kesepakatan untuk memberikan teori dan buku kumpulan slogan untuk menambah wawasan

Tercapainya kesepakatan dengan orangtua tentang pentingnya memberikan pembelajaran ketrampilan menulis slogan remaja

Tim pengabdian masyarakat akan mengajari remaja menulis slogan

Tim membimbing remaja Desa Kasemen untuk terampil menulis slogan COVID-19

Tim pengabdian masyaralat UHAMKA akan membantu 
selama ini Guru hanya menggunakan metode ceramah dalam menyampaikan materi menulis slogan

8. Sebagian remaja Desa Kasemen kurang mendapatkan latihan tentang metode menulis slogan
Guru sebaiknya melatih keterampilan menulis dan membaca slogan di sekolah sehingga remaja dapat menulis dan membaca slogan dengan baik mengajarkan cara menulis slogan COVID-19 dengan menggunakan beberapa metode sederhana dalam menulis slogan

Tim Pengabdian Masyarakat melakukan pendampingan bagi remaja desa Kasemen agar trampil menulis slogan karya sendiri

Mengingat kemampuan menulis merupakan sebuah keterampilan penting yang harus dikuasai oleh remaja, perlu adanya pembinaan dan pengembangan secara intensif dan berkesinambungan. Menulis kreatif (slogan) merupakan suatu kegiatan intelektual seseorang yang membutuhkan daya nalar, cerdas, menguasai bahasa, luas wawasannya, sekaligus peka perasaannya. Syarat-syarat tersebut menjadikan hasil penulisan slogan berbobot intelektual, tidak sekedar baitbait kenes, cengeng, dan sentimental.

Menulis dapat dilakukan dengan cara menggabungkan fakta-fakta empirik dengan daya imajinasi yang akan menjadi sebuah tulisan yang bermakna bagi manusia yang mempunyai kesadaran eksistensial. Hal ini akan tercapai apabila penulis slogan banyak mengasah kepekaan kritisnya dan banyak melaksanakan proses kreatif. Proses kreatif menulis slogan memberikan hasil yang positif bagi para remaja. Dengan menulis slogan, remaja dilatih untuk tidak meremehkan pengalaman-pengalamannya. Segala sesuatu yang dilihat dan dialaminya selalu tidak luput dari perhatiannya. Dia menjadikan semua yang dilihat, didengar, dan dirasa sebagai sesuatu yang bermakna bagi manusia. Wujud perhatian dan usaha menjadikan pengalaman-pengalaman itu sebagai sesuatu yang bermakna bagi manusia di antaranya, menuliskan apa yang dialaminya ke dalam bentuk slogan.

Hal yang perlu mendapat perhatian dalam rangka pembinaan keterampilan menulis slogan bagi remaja Desa Kasemen, tim perlu memperhatikan beberapa faktor yang menyebabkan rendahnya kemampuan menulis slogan di antaranya adalah minat remaja yang masih tergolong rendah. Pembelajaran menulis di slogan di sekolah belum dilaksanakan secara maksimal. Diduga penyebab kesulitan itu karena remaja susah untuk mengemukakan ide dan mengekspresikannya dalam bentuk bahasa tulisan maupun bahasa lisan, kesulitan mendapatkan imajinasi, kesulitan menemukan kata pertama dalam slogan, kesulitan dalam mengembangkan ide-ide cemerlang menjadi slogan, kesulitan menemukan gagasan dan pemikiran kreatif mereka di dalam tulisan.

Kesulitan yang dialami remaja Desa Kasemen pada awalnya adalah adanya anggapan di kalangan remaja Desa Kasemen, Kerawang-Banten, bahwa keterampilan menulis slogan adalah keterampilan yang sulit, membosankan, tidak menarik sehingga banyak remaja yang mengundurkan diri mengikuti kegiatan ini. Hal ini sudah kami perkirakan di awal sebagai kemungkinan-kemungkinan yang akan terjadi di lapangan, mengingat remaja paling susah diminta untuk menulis, dan pelatihan yang kami berikan diharapkan dapat mewujudkan target pencapaian pelaksaan pendampingan menulis slogan COVID-19.

Adapun capaian Target yang dihasilkan dari kegiatan Pengabdian kepada Masyarakat ini yaitu kemahiran remaja Desa Kasemen dalam penguasaan keterampilan menulis slogan. Analisis situasi mitra yang telah dijabarkan pada bagian pendahuluan membuat tim Pengabdian masyarakat dapat menguraikan solusi yang ditawarkan bagi permasalahan mitra di Desa Kasemen, Serang-Banten.

Setelah tim Pengabdian Masyarakat melaksanakan analisis situasi, menemukan permasalahan mitra, selanjutnya menjabarkan metode atau tahapan pelaksanaan solusi yang ditawarkan untuk mengatasi permasalahan mitra.

Tahap persiapan dilaksanakan untuk sosialisasi tentang rencana pelaksanaan Pengabdian Masyarakat pada remaja Desa Kasemen, Serang-Banten. Rencana kegiatan yang akan dilaksanakan pada tahap ini:

1. Penyusunan konsep kelompok pembelajaran materi pembelajaran keterampilan menggali kosa kata remaja Desa Kasemen.

2. Terbentuknya kelompok belajar keterampilan menggali diksi

3. Tercapainya kesepakatan untuk memberikan teori dan buku kumpulan slogan yang dapat dimanfaatkan untuk menambah wawasan remaja tentang slogan.

4. Tercapainya kesepakatan dengan remaja Desa Kasemen, dan tim Pengabdian masyarakat tentang pentingnya memberikan pembelajaran ketrampilan menulis dan membaca slogan pada remaja.

5. Tercapainya kesepakatan bahwa tim Pengmas dari UHAMKA akan melakukan pendampingan ini dalam bentuk kelompok belajar dengan menggunakan metode gabung, antara ceramah, tanya jawab, diskusi, inkuiri, praktek, demontrasi.

a. Ceramah: Tim memberikan pengantar tentang materi pembelajaran menulis slogan

b. Tanya jawab: Tim memberikan kesempatan kepada remaja untuk menanyakan materi yang kurang jelas atau hal lain yang berhubungan dengan materi menulis slogan.

c. Diskusi: guru membagi remaja ke dalam 5 kelompok diskusi

d. Inquiri: Metode ini digunakan untuk memancing pengetahuan remaja tentang menulis slogan. 
e. $\quad$ Demonstrasi: Metode ini digunakan agar remaja dapat mengetahui bagaimana cara menulis slogan yang baik. Tim Pengmas mencontohkan cara menulis slogan yang baik.

f. Latihan/Praktik: Setelah memberikan penjelasan dan telah memberikan contoh, remaja diminta untuk menulis slogan COVID-19 tersebut, lalu membacakan slogan yang telah ditulis di depan teman- temannya.

Evaluasi terhadap pelaksanaan kegiatan Pengabdian pada mitra. Instrumen evaluasi yang digunakan adalah seperti pada Tabel 2.

Tabel 2. Instrumen evaluasi pengabdian

\begin{tabular}{|c|c|c|}
\hline No & Jenis Evaluasi & Indikator \\
\hline 1 & Pemanfaatan kelompok belajar & $\begin{array}{l}\text { Tingkat kedatangan remaja berdasarkan jumlah remaja yang datang } \\
\text { ke tempat kelompok belajar selama pelaksanaan Pengabdian } \\
\text { Masyarakat }\end{array}$ \\
\hline 2 & $\begin{array}{l}\text { Evaluasi kepuasaan pelayanan (disebarkan } 2 \text { kali } \\
\text { selama Pengabdian Masyarakat, untuk mengetahui } \\
\text { tingkat kepuasan remaja Desa Kasemen terhadap } \\
\text { kelompok belajar dengan menggunakan skala Likert, } \\
\text { yaitu: } \\
1 \text { = sangat tidak puas } \\
2 \text { = tidak puas } \\
3=\text { puas } \\
4=\text { sangat puas }\end{array}$ & $\begin{array}{l}\text { Didasarkan pada konsep kepuasaan remaja dengan kualitas kelompok } \\
\text { belajar (Budiharto, 2015) yaitu: } \\
\text { Kondisi media pembelajaran yang digunakan } \\
\text { Keberhasilan pembelajaran yang dilakukan remaja yang mampu } \\
\text { menulis slogan COVID-19 } \\
\text { Kepedulian remaja untuk mengedukasi masyarakat pada kondisi } \\
\text { COVID-19. }\end{array}$ \\
\hline
\end{tabular}

Bentuk aktivitas yang dirancang untuk dapat Memotivasi remaja Desa Kasemen agar mereka mampu menulis slogan dengan cara; menumbuhkan minat remaja, memotivasi remaja untuk tanggap dan mau belajar menulis slogan, menggunakan teknik/strategi menulis slogan yang bervariasi, membimbing dan mendampingi remaja saat menulis slogan, menggunakan media video yang menarik. Media sebagai salah satu komponen komunikasi yang digunakan untuk menyalurkan pesan (bahan pembelajaran), sehingga dapat merangsang perhatian, minat, pikiran, dan perasaan remaja dalam kegiatan belajar untuk mencapai tujuan belajar.

\section{HASIL DAN PEMBAHASAN}

Kegiatan Pendampingan Program Kemitraan Masyarakat FKIP UHAMKA melalui Pelatihan Menulis Slogan COVID-19 bagi Remaja Desa Kasemen, Kerawang Banten dan Bantuan Sembako bagi para Sopir Angkot Ciputat-Parung yang terdampak COVID-19 telah terlaksana dengan baik. Dokumentasi kegiatan sebagaimana pada Gambar 1 dan Gambar 2. Hal ini dapat dievaluasi berdasarkan respon dan pertanyaan yang disampaikan oleh peserta kepada tim pengabdian masyarakat UHAMKA. Respon dan pertanyaan mengindikasikan minat dan keingintahuan cukup banyak diajukan peserta. Hal ini dapat dilihat dari tabel parameter yang dievaluasi seperti tertera pada Tabel 3.

Tabel 3. Parameter respon peserta

\begin{tabular}{|c|c|c|c|c|}
\hline \multirow[t]{2}{*}{ No. } & \multirow[t]{2}{*}{ Parameter } & \multicolumn{3}{|c|}{ Persentasi (\%) } \\
\hline & & A & $\mathrm{B}$ & $\mathrm{C}$ \\
\hline 1. & Penerimaan Materi & V & - & - \\
\hline 2. & Pemahaman & v & - & - \\
\hline 3. & Aplikasi & - & V & - \\
\hline
\end{tabular}

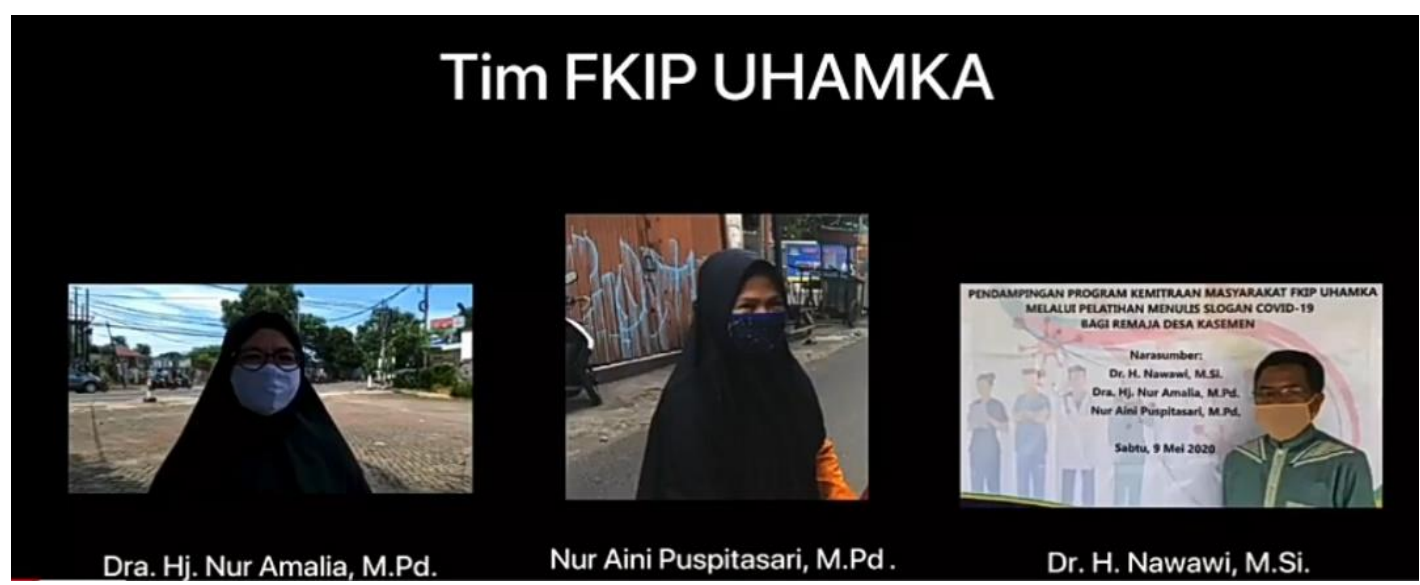

Gambar 1.Tim FKIP UHAMKA yang melakukan kegiatan pelatihan menulis Slogan Covid-19 

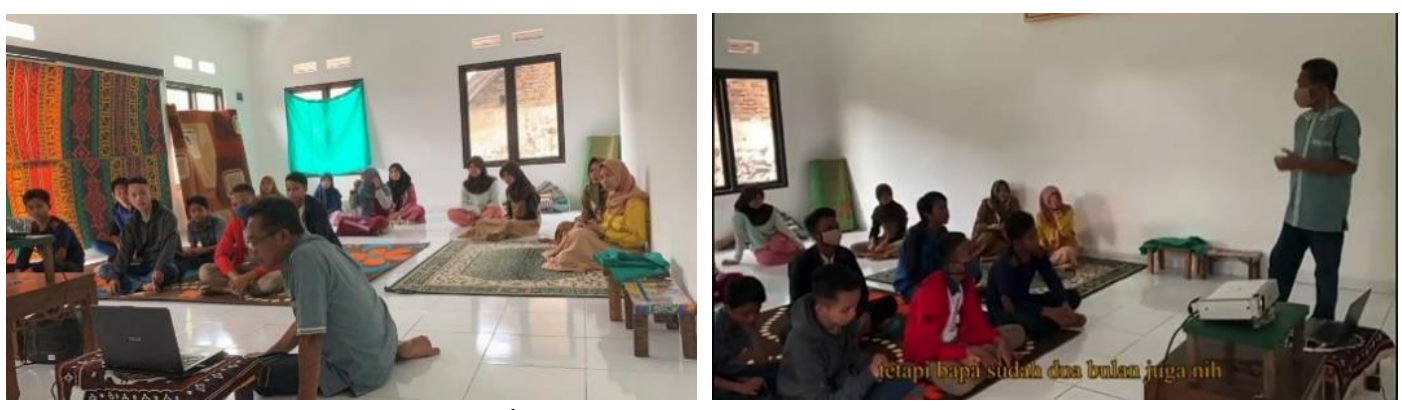

Gambar 2. Kegiatan Penyajian Materi

Pendampingan Program Kemitraan Masyarakat FKIP UHAMKA disampaikan melalui penyajian materi, tanyajawab, inquiri, praktik menuis slogan dan demonstrasi pembacaan slogan yang telah dibuat remaja desa Kasemen. Hasil pendampingan ini dapat berjalan lancar. Hal ini terlihat dari respon, pertanyaan yang diberikan oleh peserta kepada para penyuluh, dan produk slogan yang mereka buat dibacakan di hadapan teman-teman yang lain. Dengan demikian, setelah mengikuti pelatihan ini, remaja Desa Kasemen dapat mempraktekkan kemampuan menulis slogan dengan baik. Setiap kelompok tampak terlihat kompak pada saat diskusi, dan saling isi, sehingga waktu yang diperlukan untuk bertanya jawab dapat dimanfaat dengan baik. Kondisi peserta seperti ini sangat membantu/mempermudah para penyuluh dalam mentransfer materi. Para penyuluh berusaha menyampaikan materi sejelas dan/sesederhana mungkin, dan berusaha menghindarkan penggunaan istilah-istilah khusus. Kalaupun ada yang kurang mengerti dengan istilah yang digunakan para penyuluh, peserta dapat menanyakan langsung kepada para penyuluh.

Kendala ataupun hambatan dalam Pendampingan Program Kemitraan Masyarakat FKIP UHAMKA melalui Pelatihan Menulis Slogan COVID-19 bagi Remaja Desa Kasemen, Kerawang-Banten dapat dikatakan tidak ada, karena para peserta yang mengikuti pelatihan ini adalah remaja kelas VIII-X yang memang sedang mempelajari materi ini. Para peserta sangat antusias diminta menulis slogan COVID-19. Ahamdulillah mereka berani tampil dengan penuh rasa percaya diri ketika diminta untuk membacakan hasil tulisan slogan mereka. Meskipun malu-malu, tetapi keyakinan akan kemampuan mereka dalam menulis slogan COVID-19 yang mereka bacakan membuat teman-teman mereka mendengarkan dan sekali-sekali berteriak memberikan komentar pada slogan yang mereka baca, dan ketika selesai membacakan slogannya, mendapatkan tepuk tangan yang meriah dari teman-temannya, dan semua terlihat senang. Mereka juga sudah berani mengacungkan tangan untuk diberi kesempatan unjuk kerja membacakan slogan di depan teman-temannya.

Selain mengadakan pendampingan pada kegiatan menulis slogan tim pengmas juga memberikan bantuan sembako kepada 20 orang sopir angkot trayek Ciputat-Parung-Parung yang terdampak COVID-19 (Gambar 3).

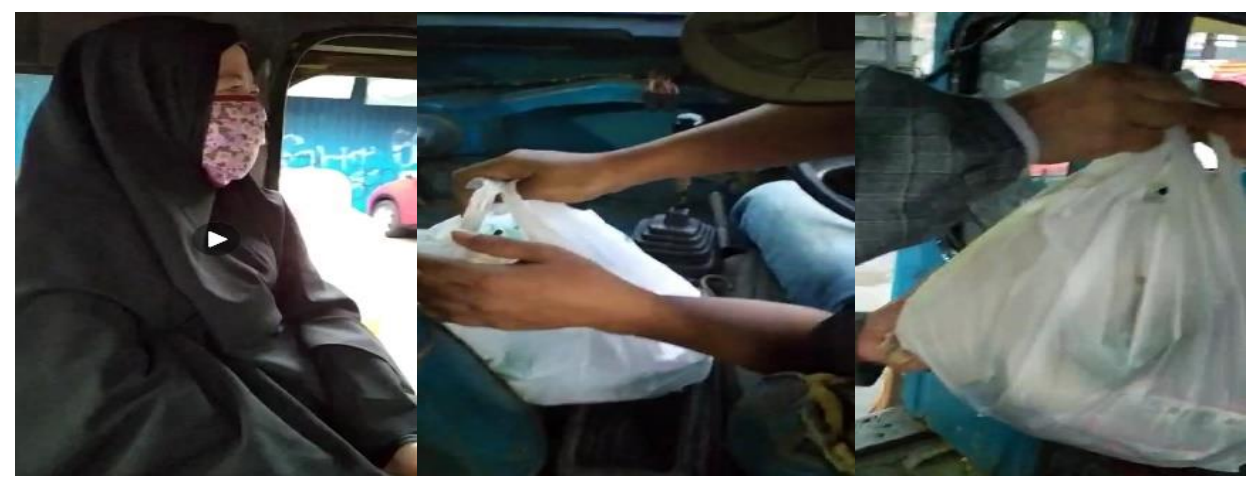

Gambar 3. Kegiatan berbagi sembako kepada sopir angkot.

\section{KESIMPULAN}

Kegiatan Pendampingan Program Kemitraan Masyarakat FKIP UHAMKA melalui Pelatihan Menulis Slogan COVID-19 bagi Remaja Desa Kasemen, Kerawang-Banten dan Bantuan Sembako bagi para Sopir Angkot Ciputat-Parung yang terdampak COVID-19 dapat dilaksanakan sesuai dengan apa yang diharapkan oleh para pendamping program kemitraan masyarakat. Hal ini dapat dilihat dari pertanyaan yang diajukan kepada para penyuluh, dan minat peserta untuk mengikuti pelatihan ini serta harapan mereka agar kegiatan pendampingan ini dapat terus berlanjut. Selain memberikan pelatihan menulis slogan COVID-19 pada remaja Desa kasemen, tim juga memberikan bantuan sembako bagi para sopir angkot trayek Ciputat-Parung-yang terdampak COVID-19. Dari pengalaman Pendampingan saran yang dapat tim penyuluh berikan adalah (1) Diperlukan usaha dan kemauan untuk mencoba dan mencoba lagi bila gagal, diperlukan kesabaran dan usaha maksimal agar berhasil. Jika sudah berhasil baik dari segi teknik dan keberanian untuk tampil di muka umum, diperlukan kreativitas dalam mengolah kosa kata dan penggunaan diksi yang tepat sehingga remaja terampil menulis dan membaca slogan dengan baik dan mampu menumbuhkan rasa percaya diri mereka. (2) Setelah mengikuti pelatihan 
ini disarankan kepada para peserta pelatihan untuk terus berlatih mengasah kemampuan menulis slogan dan trampil membaca slogan sebagai upaya untuk meningkatkan kepercayaan dirinya dalam berbicara di depan umum. (3) Dilihat dari antusiame peserta pelatihan, diharapkan kepada lembaga pengabdian masyarakat memfasilitasi kegiatan serupa yang menyentuh langsung dengan kebutuhan masyarakat, sehingga selain dapat menumbuhkan semangat untuk meningkatkan keberanian dan memupuk rasa percaya diri yang tinggi bahwa mereka pasti bias asal mau terus berlatih dan mencoba.

\section{UCAPAN TERIMA KASIH}

Ucapan terima kasih yang tulus kami sampaikan kepada Ketua LEMLIT, Prof. Dr. Nani Solihati, M.Pd beserta tim yang telah memfasiltasi dan mengarahkan tim kami dalam kegiatan Pengabdian Masyarakat ini di tengah wabah Covid-19.

\section{REFERENSI}

Cirrincione, L., Plescia, F., Ledda, C., Rapisarda, V., Martorana, D., Moldovan, R. E., Theodoridou, K., \& Cannizzaro, E. (2020). COVID-19 Pandemic: Prevention and protection measures to be adopted at the workplace. Sustainability (Switzerland), 12(9), 1-18. https://doi.org/10.3390/SU12093603

Dube, G. (2020). Descriptive review of epidemiological geographic mapping of coronavirus disease 2019 (COVID-19) on the internet. Biomedical and Biotechnology Research Journal, 4(2), 83-89. https://doi.org/10.4103/bbrj.bbrj_50_20

Fatimah, D., Asriani, D. D., Zubaedah, A., \& Mardhiyyah, M. (2020). Ora obah, ora mamah: Studi Kasus Gender pada Sektor Informal di Masa Pandemi COVID-19. SRI INSTITUTE, Yogyakarta.

Sharma, A., Tiwari, S., Kanti, M., \& Louis, J. (2020). Since January 2020 Elsevier has created a COVID-19 resource centre with free information in English and Mandarin on the novel coronavirus COVID- 19. The COVID-19 resource centre is hosted on Elsevier Connect, the company's public news and information. Science, 56(2), 1-14. https://www.ncbi.nlm.nih.gov/pmc/articles/PMC7286265/

Suryani, N. L. (2020). Covid 19 And New Normal. In Desanta Muliavisitama (Issue L).

Udin, A. et al. (2020). Covid-19 \& Work From Home. In Desanta Muliavisitama.

Wu, Y. C., Chen, C. S., \& Chan, Y. J. (2020). The outbreak of COVID-19: An overview. Journal of the Chinese Medical Association, 83(3), 217-220. https://doi.org/10.1097/JCMA.0000000000000270

Yang, Y., Peng, F., Wang, R., Guan, K., Jiang, T., Xu, G., Sun, J., \& Chang, C. (2020). The Deadly Coronaviruses: The 2003 SARS Pandemic and The 2020 Novel Coronavirus Epidemic in China, The Company's Public News and Information. Journal of Autoimmunity, 109(January), 102487. https://www.sciencedirect.com/science/article/pii/S0896841120300470?via\%3Dihub

Yi, Y., Lagniton, P. N. P., Ye, S., Li, E., \& Xu, R. H. (2020). COVID-19: What has been learned and to be learned about the novel coronavirus disease. International Journal of Biological Sciences, 16(10), 1753-1766. https://doi.org/10.7150/ijbs.45134

Yuliana, Y. (2020). Corona virus diseases (Covid-19): Sebuah tinjauan literatur. Wellness And Healthy Magazine, 2(1), 187-192. https://doi.org/10.30604/well.95212020 